\title{
Dicrocoeliosis in extensive sheep farms: a survey
}

\author{
Antonio Scala ${ }^{1,2 \dagger}$, Claudia Tamponi ${ }^{1 \dagger}$, Giorgia Dessì , Giampietro Sedda ${ }^{1}$, Giuliana Sanna', Silvia Carta ${ }^{1}$, \\ Andrea Corda ${ }^{1}$, Philippe Jacquiet ${ }^{3}$, Antonio Varcasia ${ }^{1,2^{*}}$ (D) and Ciriaco Ligios ${ }^{4}$
}

\begin{abstract}
Background: This study investigated the epidemiological and molecular aspects of dicrocoeliosis in extensive sheep farms.

Methods: From 2013 to 2014, copromicroscopical analyses in 190 dairy sheep farms and anatomo-pathological inspections in six slaughterhouses were carried in Sardinia, Italy. Rectal faecal samples were analyzed using the FLOTAC ${ }^{\circledR}$ method, and anatomo-pathological examinations were based on detecting thickened terminal bile ducts (TTBDs). In addition, genetic analyses were conducted on representative DNA samples of adult Dicrocoelium spp.

Results: Ninety-seven (51.1\%) out of 190 sheep farms were coprologically positive for Dicrocoelium spp. In the liver, on the surface and cut surface, TTBDs were reported in 40.1\% (309/770) and 15.3\% (118/770) of the animals examined, respectively, with an overall prevalence of $25.5 \%$ (196/770). No intraspecific genetic variation was observed among the Dicrocoelium dendriticum isolates.

Conclusions: Our survey reveals the widespread presence of D. dendriticum in Sardinia, although seasonal, geographical and climatic conditions might be key factors in modulating the infection prevalence. Examining typical lesions due to $D$. dendriticum in the liver in abattoirs can be used as a marker for tracking chronic dicrocoeliosis infection.
\end{abstract}

Keywords: Sheep, Breeding, Trematoda, Dicrocoelium dendriticum, Epidemiology

\section{Background}

Dicrocoeliosis is a disease caused by several species of the genus Dicrocoelium Dujardin, 1845 (Trematoda: Digenea), which live in the hepatic bile ducts and gallbladder of domestic and wild ruminants [1]. Liver lesions due to dicrocoeliosis, such as abscesses, granulomas and fibrosis, as well as bile duct proliferation have also been described in the New World camelids (llamas and alpacas) [2-4]. Occasionally, Dicrocoelium spp. can also infect rabbits, pigs, dogs, horses and humans [5]. The various species of Dicrocoelium have different geographical distributions, with $D$. dendriticum being the most widespread globally, being found in Europe, Asia (China

\footnotetext{
*Correspondence: varcasia@uniss.it

${ }^{\dagger}$ Antonio Scala and Claudia Tamponi are equal contributors

${ }^{1}$ Laboratory of Parasitology, Veterinary Teaching Hospital, Department

of Veterinary Medicine, University of Sassari, Sassari, Italy

Full list of author information is available at the end of the article
}

and the Indo-Malayan region), Japan, North Africa and Australia [3, 5], while Dicrocoelium hospes, Dicrocoelium chinensis and Dicrocoelium suppereri [3] have a limited distribution in Africa, Asia and some areas of western Europe, respectively [6-9]. To complete its life-cycle, Dicrocoelium develops within the body of some land snails and ant species, which act as first and second intermediate hosts, respectively [10].

Dicrocoeliosis is commonly considered to be of negligible economic importance, resulting only in livers being discarded during meat inspection at slaughterhouses [11, 12]. In reality however, production performance losses in animals are often not associated with dicrocoeliosis, as the infection remains underestimated in field conditions because of its subclinical evolution [13]. The pathological effects related to dicrocoeliosis in ruminants can sometimes be overshadowed by concurrent liver infections (i.e. cystic echinococcosis, cysticercosis caused by Taenia 
hydatigena, fasciolosis); consequently, veterinarians and farmers may underestimate the importance of this disease [14-16]. Infected animals with a parasitic burden of under 1000 individuals of $D$. dendriticum usually do not show any clinical manifestations [17] and even infections with 4000 parasites can cause mild symptoms [8]. In fact, in previous work we reported that only $33.3 \%$ of practitioners diagnose dicrocoeliosis according to clinical symptoms [18].

In addition, sheep with $D$. dendriticum are often co-infected with other parasites (e.g. gastrointestinal and bronchopulmonary nematodes) making it quite difficult to identify the specific outcomes of each individual parasitosis [5].

Another aspect that may lead to an underestimation of dicrocoeliosis is that this parasitosis is generally not diagnosed with an appropriate coprodiagnostic analysis, thus infected animals are not identified [19]. As a consequence, the infection becomes increasingly persistent, with cumulative effects $[19,20]$. Moreover, serological techniques do not provide reliable information for diagnosing dicroceliosis, although these tests may be useful when investigating prepatent infections [21].

Sardinia (Italy) has a long-established sheep farming tradition with over 3,200,000 sheep, which represent $45 \%$ of the entire stock of the Italian sheep population [22]. Due to the insularity and the high concentration of animals, which all belong to the Sardinian sheep breed, the island is regarded as a unique geographical area for epidemiological studies on parasites [15, 16, 23-28].

Most of the data on sheep dicrocoeliosis regarding Sardinia have demonstrated that this parasitosis is endemic, though much of the data is not recent $[29,30]$.

In this study, we investigated sheep dicrocoeliosis in Sardinia with particular emphasis on parasitological and molecular aspects in order to provide new insights into its epidemiology in extensive sheep farms.

\section{Methods}

\section{Copromicroscopical survey in sheep farms}

The sample size of the farms studied was estimated considering 15,387 Sardinian sheep farms (National Data Bank of the Italian Ministry of Health; https://www.vetin fo.it) with an expected Dicrocoelium spp. prevalence of $15 \%$, and confidence level of $95 \%$ (http://www.raoso ft.com/samplesize.html).

A total of 190 dairy sheep farms in Sardinia (Fig. 1) were investigated from 2013 to 2014 . Within each flock, 15 individual rectal faecal samples from sheep older than 3 years of age were collected. These samples were then split into three different faecal pools from five animals, which were then analysed using the FLOTAC ${ }^{\circledR}$ method with a heavy saturated zinc sulphate solution, specific gravity (SG) 1350) [31, 32].

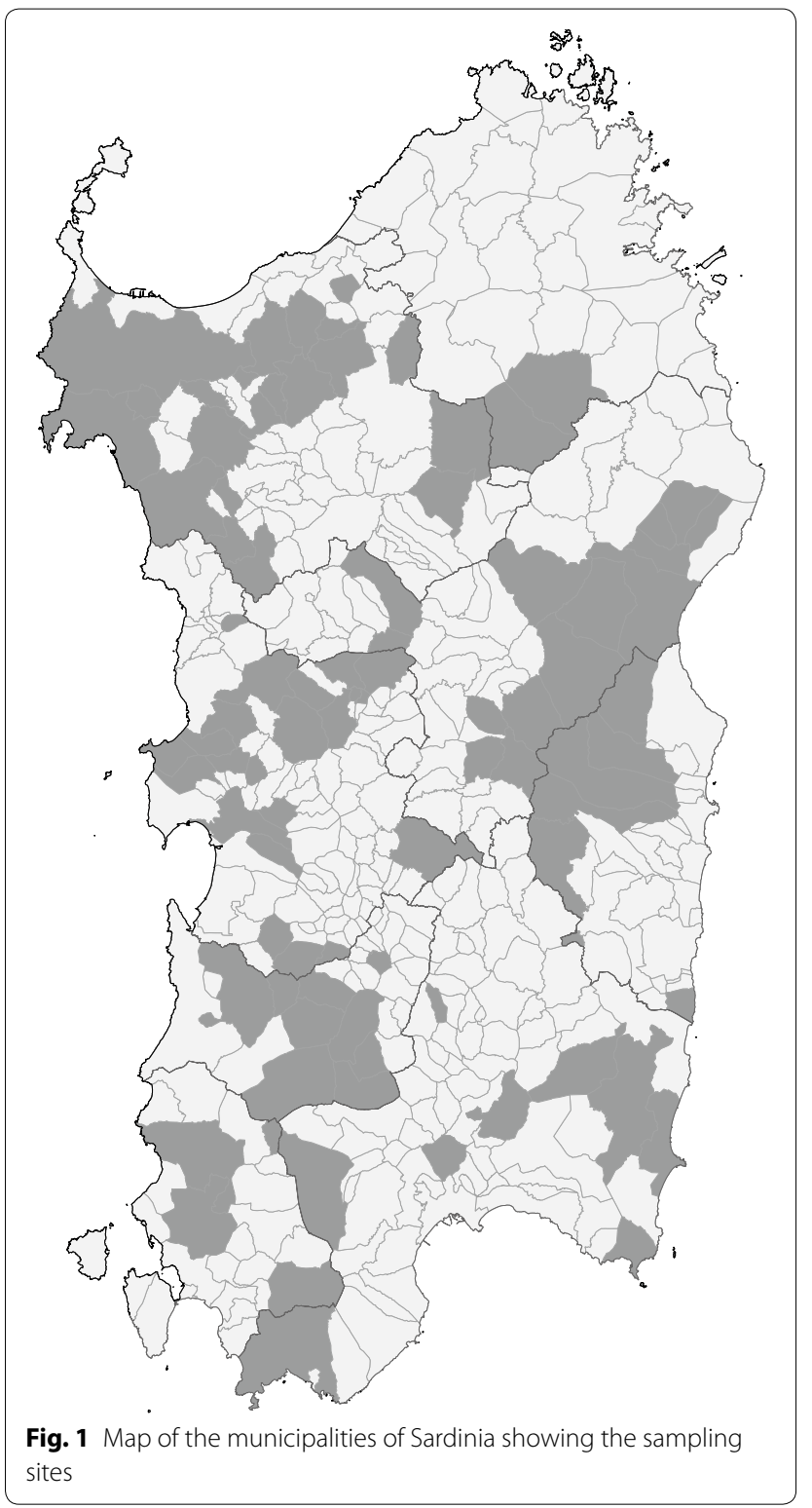

Data were processed for each farm considering the eggs per gram (EPG) mean of the three faecal pools.

The data were then stratified by geolocalisation in the four provinces of Sardinia (Sassari, Cagliari, Nuoro and Oristano) (Fig. 1). Farms were grouped according to the EPG means values into four classes: (i) $\leq 50$ EPG; (ii) $>50$ and $\leq 100$ EPG; (iii) $>100$ and $\leq 300$; (iv) $>300$ EPG.

The mean intensity (MI) was obtained considering the arithmetic mean of the EPG values in the total number of the infected animals.

\section{Epidemiological survey in slaughterhouses}

The sample size of the studied animals was determined considering a total of 3,206,821 heads of Sardinian dairy sheep (National Data Bank of the Italian Ministry of 
Health; https://www.vetinfo.it) with an expected Dicrocoelium spp. prevalence of $15 \%$, and confidence level of 95\% (http://www.raosoft.com/samplesize.html).

From 2013 to 2014, 770 Sarda sheep slaughtered in six different abattoirs in Sardinia, were submitted to anatomo-pathological examination to detect the liver parasites and to evaluate the typical thickened terminal bile duct (TTBD) lesions [33, 34], following the EEC Inspection Regulation No. 854 of 2004 (Annex 1, Section IV, Chapter II, point 5) [35] and the methods illustrated by Marcato [36].

To perform the anatomo-pathological examination, seven hepatic areas were selected: right lobe (RL) and left lobe (LL) of both the diaphragmatic face (DF) and visceral face $(\mathrm{VF})$, quadrate lobe $(\mathrm{QL})$, caudate lobe $(\mathrm{CL})$ and finally the cut surface. For each area the severity/ extension of the lesions indicative of a TTBD pattern were scored as follows: (0) absence of TTBD; (1) presence of rare TTBD; (2) $\leq 5 \mathrm{~cm}^{2}$; (3) $5-7.5 \mathrm{~cm}^{2}$; (4) $7.5-10 \mathrm{~cm}^{2}$; and (5) $>10 \mathrm{~cm}^{2}$.

Subsequently, according to the guidelines of the World Association for the Advancement of Veterinary Parasitology (WAAVP) [37], an incision on the gall-bladder wall was performed, and the entire liver parenchyma was cut into $0.5-1.0 \mathrm{~cm}$ slices, in order to identify and count the adult parasites. The parasitic burdens were classified into five classes, based on the number of parasites found in the organ: (i) $\leq 50$; (ii) $50-100$; (iii) $100-300$; (iv) $300-$ 1000; and (5) $>1000$. Five adult Dicrocoelium spp. were taken from each liver in order to confirm the species based on published morphological keys [6].

\section{Genetic analysis}

DNA from 15 adult Dicrocoelium spp. representing all four provinces of Sardinia was extracted using a commercial kit, PureLink ${ }^{\circledR}$ Genomic DNA Mini Kit (Invitrogen, Carlsbad, CA, USA) by following the manufacturer's instructions. DNA samples were amplified by PCR for the regions internal transcribed spacer (ITS2) with the primers and the methods described elsewhere [6, 40]. PCR products were purified using a commercial kit (Nucleospin Gel and PCR Clean Up; Macherey-Nagel, Düren,
Germany) and sent to an external sequencing service (Eurofins Genomics, Ebersberg, Germany). Sequences were assembled manually with the aid of the CLUSTAL W multiple alignment program [38], and analyzed using the basic local alignment search tool (BLAST) available on the NCBI website (https://blast.ncbi.nlm.nih.gov/ Blast.cgi.).

\section{Statistical analysis}

Data were processed using MINITAB v.12.1 (Minitab Inc., State College, PA, USA) and EpiInfo v.6.04 (CDC, Atlanta, GA, USA). A Chi-square test was performed to compare the prevalence in the four provinces. In order to compare the prevalence rates found in the different seasons, a chi-square trend test was used and odds ratio (OR) values were calculated. Mann-Whitney and Kruskal-Wallis non-parametric tests were used to compare the EPG means. Pearson's correlation test was performed in order to evaluate the correlations between the parasite burden and TTBD score.

\section{Results}

\section{Copromicroscopic survey}

Ninety-seven out of the 190 examined farms were coprologically positive for Dicrocoelium spp. (51.1\%; 95\% CI: 43.91-58.07\%). Quantitative coprological analysis of Dicrocoelium spp. showed a EPG mean ( \pm standard deviation, SD) of 31.2 \pm 68.7 and a MI of 61.1 EPG. Interestingly, dicrocoeliosis prevalence was significantly lower in the summer (37.5\%) compared to the winter (90.9\%), when the odds ratio (OR) values were four times higher than in other seasons (Table 1).

Table 2 shows the prevalence, farm EPG mean, MI values for Dicrocoelium spp. in the faecal pools and OR values in the four provinces. Regarding the Dicrocoelium spp. prevalence, the four provinces showed significant differences $\left(x^{2}=23.89, d f=3, P<0.0001\right)$; there were also statistically significant differences in EPG means (Kruskal-Wallis H-test: $\chi^{2}=30.88, P<0.0001$ ). The province of Nuoro showed the highest prevalence and EPG

Table 1 Seasonal trend of prevalence, EPG mean excretion and odds ratio values for D. dendriticum in farm faecal pools samples

\begin{tabular}{llllll}
\hline Season & Total no. of farms & No. of positive farms & \% positive farms ${ }^{\text {a }}$ & EPG Mean \pm SD $^{\text {b }}$ & Odds ratio \\
\hline Spring & 13 & 9 & 69.2 & $26.8(29.4)$ & 1.00 \\
Summer & 120 & 45 & 37.5 & $22.1(65.4)$ & 0.27 \\
Autumn & 46 & 33 & 71.7 & $52.8(80.3)$ & 1.13 \\
Winter & 11 & 10 & 90.9 & $44.9(68.8)$ & 4.44
\end{tabular}

${ }^{\mathrm{a}} X^{2}$ trend $=11.558, d f=3, P<0.0007$

b Kruskal-Wallis test: $H=24.74, P<0.0001$ 
Table 2 Prevalence, EPG mean values, mean intensity and odds ratio values for D. dendriticum in farm faecal samples in each province of Sardinia

\begin{tabular}{|c|c|c|c|c|c|c|}
\hline Province & Total no. of farms & No. of positive farms & Prevalence (\%) & EPG Mean ${ }^{b}$ & Mean intensity (EPG) & Odds ratio \\
\hline Cagliari & 32 & 16 & 50.0 & 55.5 & 111.0 & 1.00 \\
\hline Oristano & 44 & 22 & 50.0 & 21.2 & 42.4 & 1.00 \\
\hline Sassari & 84 & 32 & 38.1 & 16.4 & 43.0 & 0.62 \\
\hline Nuoro & 30 & 27 & 93.3 & 61.4 & 66.8 & 9.00 \\
\hline
\end{tabular}

${ }^{2}=23.89, d f=3, P<0.0001$

b Kruskal-Wallis test: $H=30.88, P<0.0001$

Table 3 Prevalence and odds ratios of D. dendriticum in livers examined at abattoirs

\begin{tabular}{llll}
\hline Infection class $^{\mathrm{a}}$ & $\begin{array}{l}\text { No. of positive } \\
\text { livers }\end{array}$ & Prevalence $(\%)^{\mathrm{b}}$ & $\begin{array}{l}\text { Odds ratio } \\
\text { exposure } \\
\text { score }\end{array}$ \\
\hline$\leq 50$ & 106 & 54.1 & 1.00 \\
$>50$ to $\leq 100$ & 37 & 18.9 & 0.20 \\
$>100$ to $\leq 300$ & 25 & 12.8 & 0.12 \\
$>300$ to $\leq 1000$ & 22 & 11.2 & 0.11 \\
$>1000$ & 6 & 3.0 & 0.03 \\
\hline
\end{tabular}

a No. of adult parasites

b $x^{2}$ trend $=147.25, d f=3, P<0.0001$

means for dicrocoeliosis, as well as the highest OR values $(\mathrm{OR}=9)$ (Table 2).

On-farm overall prevalence of Dicrocoelium by year was $36.3 \%(45 / 124)$ in 2013 and $78.8 \%(52 / 66)$ in 2014. There were statistically significant differences in prevalence between the two years $\left(\chi^{2}=31.13, d f=1\right.$, $P<0.0001)$, as well as in the EPG means, which were $20.7 \pm 63$ EPG in 2013 and 50.8 \pm 89.3 EPG in 2014 (Mann-Whitney U-test: $U=10554.0, P=0.0004$ ).
A total of $156(82.1 \%)$ of the farms investigated were negative or with EPG mean values of $\leq 50 \mathrm{EPG}$, while 17 (9\%) had EPG mean values of 50-100 EPG, 13 (6.8\%) had EPG mean values of 100-300 EPG and only four (2.1\%) had EPG mean values of $>300$ EPG. These values were statistically different $\left(\chi^{2}=443.09, d f=3, P<0.0001\right)$.

\section{Epidemiological survey in slaughterhouses}

The anatomo-histopathological examination of the livers showed a Dicrocoelium spp. prevalence of $25.5 \%$ (95\% CI: $0.22-0.28 \%)(196 / 770), 54.1 \%$ of which harboured less than 50 adult parasites per organ, while only $3 \%$ harboured over 1000 parasites (Table 3).

TTBD on the surface and the cut surface were reported in $40.1 \%(309 / 770)$ and $15.3 \%$ (118/770) of examined livers, respectively (Fig. 2). The hepatic areas most involved were the RL of VF and CL with a prevalence of $24.8 \%$ (191/770) and 16.8\% (129/770), respectively. TTBD was not observed in the quadrate lobe. Our results did not show any match between the presence of parasites in the examined livers (25.5\%) and the TTBD both on the surface $(40.1 \%)$, and the cut surface $(15.3 \%)\left(\chi^{2}=121.62\right.$, $d f=2, P<0.0001)$. The score values were higher in RL VF
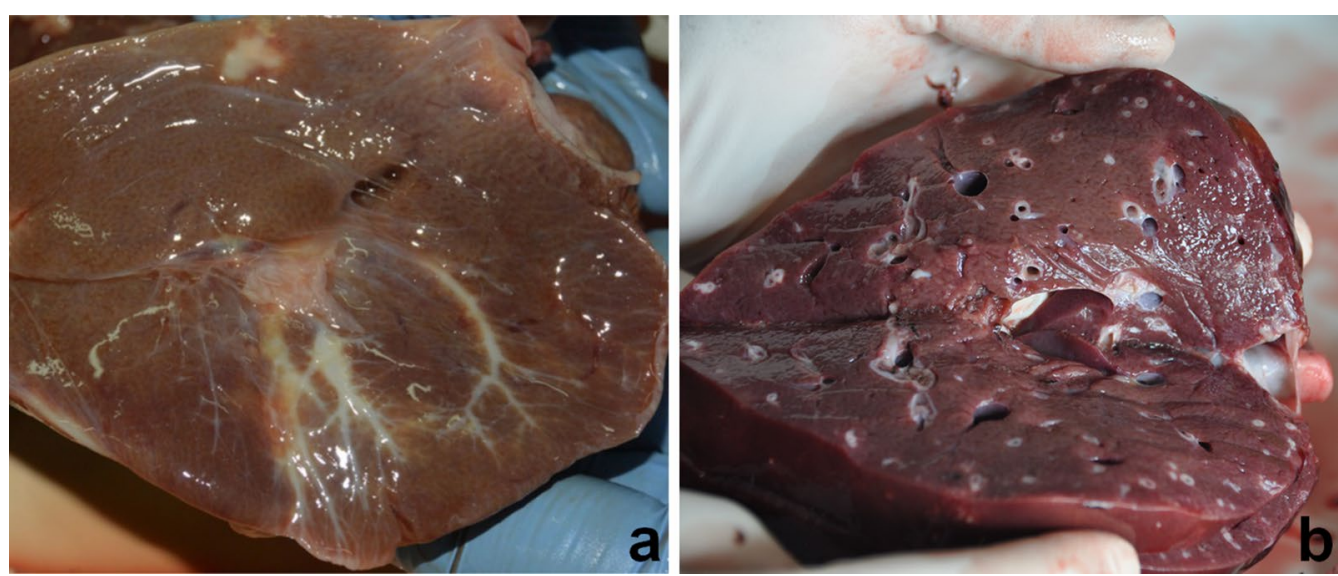

Fig. 2 Thickened terminal bile duct (TTBD) on the surface (a) and cut surface (b) of the liver 
Table 4 Score of livers reporting thickened terminal bile duct (TTBD) in the different examined areas: right lobe (RL) and left lobe (LL) of diaphragmatic face (DF) and visceral face (VF), caudate lobe (CL) and cut surface

\begin{tabular}{|c|c|c|c|c|c|c|}
\hline \multirow[t]{2}{*}{ Localisation TTBD } & \multirow[t]{2}{*}{ No. positive (\%) } & \multicolumn{5}{|c|}{ Score, no. positive (\%) } \\
\hline & & 1 & 2 & 3 & 4 & 5 \\
\hline RL DF & $45(5.8)$ & $34(4.4)$ & $11(1.4)$ & $0(0)$ & $0(0)$ & $0(0)$ \\
\hline LLDF & $5(0.7)$ & $5(0.7)$ & $0(0)$ & $0(0)$ & $0(0)$ & $0(0)$ \\
\hline RL VF & $191(24.8)$ & $95(12.3)$ & $79(10.3)$ & $6(0.8)$ & $11(1.4)$ & $0(0)$ \\
\hline LLVF & $124(16.1)$ & $67(8.7)$ & $51(6.6)$ & $6(0.8)$ & $0(0)$ & $0(0)$ \\
\hline $\mathrm{CL}$ & $129(16.8)$ & $6(0.8)$ & $107(13.9)$ & $10(1.3)$ & $6(0.8)$ & $0(0)$ \\
\hline Cut surface & $118(15.3)$ & $45(5.8)$ & $45(5.8)$ & $11(1.4)$ & $17(2.2)$ & $0(0)$ \\
\hline
\end{tabular}

than the other hepatic localizations. Detailed data are reported in Table 4.

There was a significant positive correlation between the parasite burden and the scores for the severity/extension of TTBD as follows: RL of DF ( $r=0.538, P<0.0001)$, RL VF $(r=0.484, P<0.0001)$, LL VF $(r=0.374, P<0.0001)$, CL $(r=0.351, P<0.0001)$ and the cut surface $(r=0.338$, $P<0.0001)$. According to Colton [39], the correlation, based on reported $r$-values, between the parasitic burden and RL VF was moderate to good, while the correlations between the parasitic burden and the other hepatic localizations were quite good. Using the morphological examination, all Dicrocoelium spp. were identified as $D$. dendriticum [6].

\section{Genetic analysis}

No intraspecific variations were observed for the ITS2 gene sequence (GenBank: MG004688) among the D. dendriticum isolates. In addition, the same isolates showed a homology of 99\%, with the Iranian ITS-B haplotype isolate (GenBank: JQ966973) [40], and a homology of 99\% and $98 \%$ with the Italian isolates DQ379986.2 [41] and EF547132.1 [6], respectively. The sequence alignment of ITS showed a T/A substitution at the 153 codon with an index diversity of 0.002, compared with the sequence of the above mentioned Iranian isolate.

\section{Discussion}

The present survey provides an update of various epidemiological aspects of sheep dicrocoeliosis in Sardinia. Our copromicroscopic survey on the farms revealed the widespread presence of $D$. denditricum. However, the distribution of this parasite does not appear to be homogeneous across the island, with significantly more farms affected in the province of Nuoro, which is located in the central part of the island. It should also be highlighted that this area is characterised by the highest altitude with an average altitude of 496 meters) (http://www.comuni-italiani.it/20/clima.html) and the lowest average temperature compared with the other provinces (http://www.sar.sardegna.it/pubblicazioni/ riepiloghimensili/mensili.asp).

The EPG means and OR values appear to be statistically higher in the winter in other regions of Italy [33] and also in other countries [42-44]. In Spain it has been reported that the mountainous pastures located over 600 meters and with temperatures of $<11.8^{\circ} \mathrm{C}$ present the highest risk of infection with $D$. dendriticum [44]. These findings suggest that in some geographical areas and, especially during the winter, it is important to monitor and carry out anthelmintic treatments against Dicrocoelium spp. in sheep. We also found a different prevalence and EPG means values between the two years studied, thus suggesting that the epidemiology of the dicrocoeliosis could also be influenced by annual climatic conditions.

Our results show that the prevalence of dicrocoeliosis in Sardinia appears to be lower compared with other sheep-farming areas of Italy, such as Umbria (80\%) [45], southern Apennines (67.5\%) [1], Campania (67\%) [46] and Basilicata (62\%) [47].

Our survey demonstrated that inspections at slaughterhouses can detect the presence of the typical lesions due to $D$. dendriticum in the liver, and can thus be used to monitor the presence of chronic infections in a given flock. Underestimating the numbers of infected sheep is thus leading to the spread of parasitosis in Sardinia, which probably explains the high prevalence among sheep flocks on the island.

According to Ambrosi [33], infections with threshold values of under 100 adult parasites are not easily detected by copromicroscopical analysis. The same author [33] reported that approximately $7 \%$ of farms with EPG means values over 100 EPG could incur production losses. However, we found that only $3 \%$ of the examined livers in slaughterhouses showed a burden of over 1000 $D$. dendriticum. At the same time, the mild clinical signs might contribute to chronic infection and potentially to a 
loss of productive performance, which could be an interesting research line for further studies on this parasite.

Although previous papers have reported a high variability within $D$. dendriticum [48], both in terms of genetic and morphological parameters, no intraspecific variation was observed within our isolates and our results were consistent with findings in other surveys carried out in Italy $[6,41]$ and in Iran [40].

\section{Conclusions}

This present study show the widespread presence of $D$. dendriticum in Sardinia and highlights the key role of abattoirs and of the coprological analysis in the monitoring of parasitic diseases, through which farmers and practitioners can be given the data needed for diagnosing $D$. dendriticum and thus for setting up specific anthelmintic treatments.

\section{Abbreviations}

TTBD: thickened terminal bile duct; EPG: eggs per gram; MI: mean intensity; OR: odds ratio; RL: right lobe; VF: visceral face; CL: caudate lobe; QL: quadrate lobe; DF: diaphragmatic face; LL: left lobe; ITS: internal transcribed spacer; NDB: National Data Bank; SD: standard deviation.

\section{Acknowledgments}

The authors would like to thank Francesco Salis, head technician at the Department of Veterinary Medicine, for his valuable assistance in the laboratory, and Raffaele Marrosu and Giuseppe Bianco, ASL N.1 of Sassari for their help during the sampling.

\section{Authors' contributions}

Conceived and designed the experiments: AS. Performed the experiments: GD, GS, CT, AV and GPS. Analyzed the data: AS, AV, CT and CL. Contributed reagents/materials/analysis tools: SC, PJ, AC and CL. Wrote the paper: AV, AS and CL. Collected biological samples: CT, GD, GS and GPS. Revised the manuscript: AV, AS, PJ and CL. All authors read and approved the final manuscript.

\section{Funding}

Not applicable.

\section{Availability of data and materials}

All relevant data are included in the article. The newly generated sequence was submitted to the GenBank database under the Accession Number MG004688.

\section{Ethics approval and consent to participate}

This study was performed following the recommendations of European Council Directive (86/609/EEC) on the protection of animals.

\section{Consent for publication}

Not applicable.

\section{Competing interests}

The authors declare that they have no competing interests.

\section{Author details}

${ }^{1}$ Laboratory of Parasitology, Veterinary Teaching Hospital, Department of Veterinary Medicine, University of Sassari, Sassari, Italy. ${ }^{2}$ Inter-University Center for Research in Parasitology (CIRPAR), Via della Veterinaria 1, 80137 Napoli, Italy. ${ }^{3}$ UMT Santé des Troupeaux de Petits Ruminants, Ecole Nationale Vétérinaire de Toulouse, Toulouse, France. ${ }^{4}$ Istituto Zooprofilattico Sperimentale della Sardegna G. Pegreffi, Via Duca degli Abruzzi 8, Sassari, Sardinia, Italy.
Received: 8 March 2019 Accepted: 8 July 2019

Published online: 12 July 2019

\section{References}

1. Cringoli G, Rinaldi L, Veneziano V. A cross-sectional coprological survey of liver flukes in cattle and sheep from an area of the southern Italian Apennines. Vet Parasitol. 2002;108:137-43.

2. Wenker Ch, Halt J-M, Hertzberg H, Ossen P, Hänichen T, Brack A, Isenbügel E. Dicrocoeliosis in South American camelids. Tierarztl Prax. 1998;26:355-61.

3. Gunsser I, Hänichen T, Maierl J. Liver fluke infestation in New World camelids Parasitology, pathology, clinical findings and therapy. Tierärztl Prax. 1999;27:187-92.

4. Hilbe M, Robert N, Pospischil A, Gerspach C. Pulmonary arterial lesions in New World camelids in association with Dicrocoelium dendriticum and Fasciola hepatica infection. Vet Pathol. 2015;52:1202-9.

5. Otranto D, Traversa D. Dicrocoeliosis of ruminants: a little-known fluke disease. Trends Parasitol. 2003;19:12-5.

6. Otranto D, Rehbein S, Weigl S, Cantacessi C, Parisi A, Lia RP, et al. Morphological and molecular differentiation between Dicrocoelium dendriticum (Rudolphi, 1819) and Dicrocoelium chinensis (Sudarikov and Ryjikov, 1951) Tang and Tang, 1978 (Platyhelminthes: Digenea). Acta Trop. 2007;104:91-8.

7. Lucius R. Untersuchungen zur Biologie, Pathologie ünd Ökologie von Dicrocoelium hospes Looss, 1907 (Trematodes, Dicrocoeliidae). Dissertation zur Erlangung des Grades eines Doktors der Naturwissenschaften vorgelegt der Fakultät II (Biologie) der Universität Hohenheim. University of Hohenheim, Germany; 1981.

8. Hinaidy HK. Dicrocoelium suppereri nomen novum (syn. D. orientalis Sudarikov et Ryjikov, 1951), ein neuer Trematode fur die Parasitenfauna Osterreichs. Zentralbl Vetmed B. 1951;1983(30):576-89.

9. Tang C, Tang Z, Tang L, Cui Q, Lu H, Qian Y. Studies on the biology and epizootics of Dicrocoelium chinensis in the eastern Inner Mongol Autonomous region. Acta Zool Sin. 1983;29:340-9.

10. Campo R, Manga-Gonzalez MY, Gonzalez-Lanza C. Relationship between egg output and parasitic burden in lambs experimentally infected with different doses of Dicrocoelium dendriticum (Digenea). Vet Parasitol. 2000;87:139-49.

11. Theodoridis Y, Sotiraki S, Papadopoulos E. Observations on the blood figure of sheep infected with Dicrocoelium dendriticum. Bull Hellenic Vet Med Soc. 1999;50:300-4.

12. Arias M, Lomba C, Dacal V, Vazquez L, Pedreira J, Francisco I, et al. Prevalence of mixed trematode infections in an abattoir receiving cattle from northern Portugal and north-west Spain. Vet Rec. 2011;168:408.

13. Urqhhart GM, Armour J, Duncan JL, Dunn AM, Jennings FW. Parassitologia veterinaria. Edizione italiana a cura di Claudio Genchi. Torino: UTET; 1998.

14. Otranto D, Traversa D. A review of dicrocoeliosis of ruminants including recent advances in the diagnosis and treatment. Vet Parasitol. 2002; 107:317-35.

15. Tamponi C, Varcasia A, Pipia AP, Zidda A, Panzalis R, Dore F, et al. ISCOM ELISA in milk as screening for Neospora caninum in dairy sheep. Large Anim Rev. 2015;21:213-6.

16. Varcasia A, Tanda B, Giobbe M, Solinas C, Pipia AP, Malgor R, et al. Cystic echinococcosis in Sardinia: farmers'knowledge and dog infection in sheep farms. Vet Parasitol. 2011;181:335-40.

17. Rojo-Vazquez FA, Cordero-Del-Campillo M, Diez-Baños P, ChatonSchaffner M. Relation existant entre le nombre d'oeufs dans les feces et la charge parasitaire lors des infestations naturelles a Dicrocoelium dendriticum chez les ovins. Rev Med Vet. 1981;132:601-7.

18. Scala A, Maron P, Salamina V, Sanna G. Un "Questionnair survey" sui trattamenti antielmintici contro la dicroceliosi in una realtà ad alta vocazione per l'allevamento ovino quale la Sardegna. Large Animal Review, Acta XX Congreso Nazionale SIPAOC, Siracusa, Italy. 2012;131-3.

19. Cringoli G, Rinaldi L, Veneziano V, Capelli G, Scala A. The influence of flotation solution, sample diluition and the choice of McMaster slide area (volume) on the reliability of the McMaster technique in estimating the 
faecal egg counts of gastrointestinal strongyles and Dicrocoelium dendriticum in sheep. Vet Parasitol. 2004;123:121-31.

20. Ducommun D, Pfister K. Prevalence and distribution of Dicrocoelium dendriticum and Fasciola hepatica infections in cattle in Switzerland. Parasitol Res. 1991;77:364-6.

21. Sanchez-Andrade R, Paz-Silva A, Suarez JL, Arias M, Lopez C, Morrondo $P$, et al. Serum antibodies to Dicrocoelium dendriticum in sheep from Sardinia (Italy). Prev Vet Med. 2003;57:1-5.

22. ISTAT. Consistenza del bestiame ovino, caprino ed equino, per categoria (numero di capi) al $1^{\circ}$ dicembre. Dettaglio per regione. 2015. http://agri. istat.it/jsp/dawinci.jsp?q=plB040000010000012000\&an=2015\&ig=1\&ct $=204 \& \mathrm{id}=8 \mathrm{~A} \% 7 \mathrm{C} 16 \mathrm{~A} \% 7 \mathrm{C72A} \% 7 \mathrm{C13A \% 7C9A}$. Accessed 18 Oct 2018.

23. Scala A, Paz-Silva A, Suárez JL, López C, Díaz P, Díez-Baños P, et al. Chronobiology of Oestrus ovis (Diptera: Oestridae) in Sardinia, Italy: Guidelines to chemoprophylaxis. J Med Entomol. 2002;39:652-7.

24. Scala A, Garippa G, Varcasia A, Tranquillo VM, Genchi C. Cystic echinococcosis in slaughtered sheep in Sardinia (Italy). Vet Parasitol. 2006;135:33-8.

25. Scala A, Demontis F, Varcasia A, Pipia AP, Poglayen G, et al. Toltrazuril and sulphonamide treatment against naturally Isospora suis infected suckling piglets: Is there an actual profit? Vet Parasitol. 2009;163:362-5.

26. Scala A, Pipia AP, Dore F, Sanna G, Tamponi C, Marrosu R, et al. Epidemiological updates and economic losses due to Taenia hydatigena in sheep from Sardinia, Italy. Parasitol Res. 2015;114:3137-43.

27. Sanna G, Varcasia A, Serra S, Salis F, Sanabria R, Pipia AP, et al. Calicophoron daubneyi in sheep and cattle of Sardinia, Italy. Helminthologia. 2016:53:87-93.

28. Varcasia A, Pipia AP, Dessì G, Zidda A, Tamponi C, Pau M, et al. Morphology and genetic variability within Taenia multiceps in ruminants from Italy. Vet Parasitol. 2016;223:181-5.

29. Sanna E, Garippa G, Asoni G. Attuale diffusione delle parassitosi ovine in Sardegna. Atti SISVET. 1989;43:1299-302.

30. Scala A. Dicrocoeliosi ovina in Sardegna: tassi di prevalenza, lesioni anatomoistopatologiche e tests ematochimici. Atti FEMESPRUM. 1991;1:209-14.

31. Rinaldi L, Coles GC, Maurelli MP, Musella V, Cringoli G. Calibration and diagnostic accuracy of simple flotation, McMaster and FLOTAC for parasite egg counts in sheep. Vet Parasitol. 2011;177:345-52.

32. Rinaldi L, Biggeri A, Musella V, De Waal T, Hertzberg H, Mavrot F, et al. Sheep and Fasciola hepatica in Europe: the GLOWORM experience. Geospat Health. 2015;9:309-17.

33. Ambrosi M. Parassitologia zootecnica. Bologna: Edagricole; 1995.

34. Camara L, Pfister K, Aeschlimann A. Analyse histopathologique de foie de bovin infesté par Dicrocooelium dendriticum. Vet Res. 1996;27:87-92.

35. European Parliament and Council. EEC Inspection Regulation No. 854 of 2004 (Annex 1, Section IV, Chapter II, point 5). Strasbourg: Official Journal of the European Union; 2004.

36. Marcato SP. Patologia animale e ispezione sanitaria delle carni fresche Testo e Atlante. Bologna: Edagricole; 1995.
37. Wood IB, Amaral NK, Bairden K, Duncan JL, Kassai T, Malone JB, et al. World Association for the Advancement of Veterinary Parasitology (WAAVP) second edition of guidelines for evaluating the efficacy of anthelmintics in ruminants (bovine, ovine, caprine). Vet Parasitol. 1995;58:181-213.

38. Thompson JD, Higgins DG, Gibson TJ. CLUSTAL W: improving the sensitivity of progressive multiple sequence alignment through sequence weighting, position-specific gap penalties and weight matrix choice. Nucleic Acids Res. 1994:22:4673-80

39. Colton T. Statistica in medicina. Padova: Piccin Nuova Libraria SPA; 1991.

40. Gorjipoor S, Moazeni M, Sharifiyazdi H. Characterization of Dicrocoelium dendriticum haplotypes from sheep and cattle in Iran based on the internal transcribed spacer 2 (ITS-2) and NADH dehydrogenase gene (nad1). J Helminthol. 2015;89:158-64.

41. Maurelli MP, Rinaldi L, Capuano F, Perugini AG, Veneziano V, Cringoli G. Characterization of the $28 \mathrm{~S}$ and the second internal transcribed spacer of ribosomal DNA of Dicrocoelium dendriticum and Dicrocoelium hospes. Parasitol Res. 2007:101:1251-5.

42. Godara R, Katoch R, Yadav A, Borah MK. Dicrocoeliosis in goats in Jammu, India. J Parasitic Dis. 2014;38:201-4.

43. Pezeshki A, Aminfar H, Aminzare M. An analysis of common foodborne parasitic zoonoses in slaughtered sheep and cattle in Tehran, Iran, during 2015-2018. Vet World. 2018;11:1486-90.

44. Diaz P, Paz-Silva A, Sanchez-Andrade R, Suarez JL, Pedreira J, Arias M, et al. Assessment of climatic and orographic conditions on the infection by Calicophoron daubneyi and Dicrocoelium dendriticum in grazing beef cattle (NW Spain). Vet Parasitol. 2007;149:285-9.

45. Venditti G, Grelloni V, Filippini G. Applicazione dei Sistemi Informatici Geografici (GIS) per la definizione di mappe parassitologiche nelle regioni Umbria e Marche: indagine sulle endoparassitosi ovine. SPV Webzine. 2010;60:28-33.

46. Musella V, Catelan D, Rinaldi L, Lagazio C, Cringoli G, Biggeri A. Covariate selection in multivariate spatial analysis of ovine parasitic infection. Prev Vet Med. 2011;99:69-77.

47. Cringoli G. Parassiti in Basilicata-Quadro parassitologico di base negli allevamenti bovini ed ovini. Napoli: Mappe Parassitologiche; 2012.

48. Sandoval H, Manga-González Y, Campo R, García P, Castro JM, la Vega M. Preliminary study on genetic variability of Dicrocoelium dendriticum determined by random amplified polymorphic DNA. Parasitol Int. 1999:48:21-6.

\section{Publisher's Note}

Springer Nature remains neutral with regard to jurisdictional claims in published maps and institutional affiliations.

Ready to submit your research? Choose BMC and benefit from:

- fast, convenient online submission

- thorough peer review by experienced researchers in your field

- rapid publication on acceptance

- support for research data, including large and complex data types

- gold Open Access which fosters wider collaboration and increased citations

- maximum visibility for your research: over $100 \mathrm{M}$ website views per year

At BMC, research is always in progress.

Learn more biomedcentral.com/submissions 